\section{ONOMÁVAEIN}

Revista semestral de lingüística, filología y traducción
PONTIFICIA UNIVERSIDAD

\title{
Translation norms in the light of practical research in literary translation
}

\author{
Mercedes Enríquez-Aranda \\ Universidad de Málaga \\ España
}

\section{(c) $\odot$}

Mercedes Enríquez-Aranda: Departamento de Traducción e Interpretación, Facultad de Filosofía y Letras, Universidad de Málaga, España. | Correo electrónico: mmenriquez@uma.es 


\section{Abstract}

The study of translation norms is presently developed within the framework that relates translation to social, power and ideological aspects. Linked to both Linguistics and Sociolinguistics, norms are understood as the formulation of the values shared by a community in a certain situation. Thus they are psychological and social entities that have a social control function. From this point of view, translation norms are recurrent rules of behaviour that govern, identify and individualize the social order of the cultural system where translation takes place. The translation behaviour is then considered a communicative and a social practice.
In this article, a brief review of the current state of the art of the theoretical reflection on translation norms is offered, followed by a practical study of the Spanish translations of John Keats's odes and sonnets included in isolated editions published in Spain in the 2oth century. Normative translator behaviours find a definition, which allows a classification of translations according to the natural evolution of the socio-cultural context where translations are produced and received. Conclusions can be extrapolated to the study of the most common practices followed nowadays in the translation of poetry in Spain.

Keywords: Translation Studies; Literary Translation; Reception in Translation; Translation Norms; Sociology of Translation; Practical Research Methodology. 
"Translation reflects changes in society:

It is not a task tending to show the ultimate identity of men, But it is the vehicle of men's singularities",

\section{Octavio Paz (1990 [1971]: 11)}

\section{Introduction}

In this article a brief review of the current state of the art of the theoretical reflection on translation norms is followed by a case study that exemplifies the practical study of translation norms within literary translation.

Considering that in the normative research field within Translation Studies the interest has been focused by now on reaching a full definition of translation norms and an appropriate classification of the concept, the practical research offered in this article pursues one main objective: to suggest possible ways of superseding the traditional constrictive theoretical reflection on translation norms from a markedly social perspective. In this sense, the study of translation norms offered in this article collaborates in the development of a more complete Translation Theory that deepens the understanding of translation practice as a social act and as a communicative phenomenon.

The foundations of this research rest on the belief that, firstly, translation norms make stronger the systemic vision of translation; secondly, they reaffirm the dynamism and the complexity inherent in systems, and, finally, they reveal the manipulation that every act of translation implies when trying to reach social acceptance.

In order to progress in this kind of research it is necessary to avoid the ambiguity that characterizes the definition of translation norms. Equally, it is essential to deepen the consider- ation of translation as an act of social communication, where ideological and cultural questions become very important. Only in this way, the role of translation norms can be studied and the concept of translation as a social practice reinforced.

\section{Translation norms from an ideologi- cal and cultural perspective}

Within Translation Studies, translation norms began to be taken into consideration following the Polysystem Theory, applied by the Manipulation School to the description of translations (Enríquez Aranda, 2007b)2. Nowadays, they are developed within the framework that relates translation to social, power and ideological aspects (Hermans, 1996: 26).

International researchers such as Chesterman (1997), Hermans (1996), Nord (1997), Rabadán (1991) or Vidal Claramonte(1998), amongst others, tackle the study of translation norms from very different points of view, collaborating on the fertilization of dialogue. However, Toury's theoretical approach to translation norms is considered to be the pioneer and the most complete model on the subject (Toury, 1980 and 1995)3.

Translation norms, although originally linked to Linguistics, have a more fruitful development in the field of Sociology, where they are treated as recurrent patterns of performance that govern, identify and individualize the social order of the cultural system where translation acts. Translation behaviour is considered then a communicative practice and a social behaviour (Wolf and Fukary, 2007)

The study of translation norms becomes essential as long as norms reflect the values and attitudes of a certain socio-cultural system and

1 All quotations from languages other than English have been translated by the author of this article.

2 See Enríquez Aranda (2007b) to have a complete description and to consult bibliographical references of both the Manipulation School and the Polysystem Theory in connection with translation norms.

3 See Schäffner (1999), a dialogical book where debates among the main researchers devoted to the study of translation norms are the core subject. 
they guide translator's choices. As Hermans (1991: 165-168) states, the study of translation norms is important to develop a new Translation Theory where the absolute equivalence disappears and more attention is paid to deepening the knowledge of translation practice and the knowledge of the socio-cultural contexts in which translation takes place. Besides, translation norms strengthen the systemic vision of translation, and, therefore, they increase the value of the foreign material that translations incorporate into such translation system. Translation norms reveal the manipulation that is implicit in every act of translation. Whether translation accepts norms or transgresses them, its ultimate purpose is social acceptance.

Nevertheless, improvements should be made concerning the ambiguity of the definition of translation norms and the need of a theory that deals with both ideological and cultural factors.

On the one hand, in words of Munday (2001: 113), norms are defined as an analytical category studied through regular behaviours. From this point of view, it seems that norms exert pressure and force a prescriptive function. In a sense, translation norms are the combination between the translator's creative capacity and the external demands of the social system where they develop; that is, they are partly a description of behaviours and partly an external prescription. They should be consequently studied considering their inherent duality. Or, as Hermans (1999: 79) says, instead of being treated as constraints, they could be studied as templates that offer solutions to translation problems.

On the other hand, although, following Hermans (1996: 40-42; 1999: 79), the study of trans- lation norms implies considering translation within the social frame in which it occurs, there is still great need of a definite development of a theory that deals with cultural factors in relation to the very concept of translation. Hung (2005: ix) agrees with this premise supporting the idea that the study of the national discourse among Translation Studies circles can provide more information about the cultural and ideological preferences than the discipline's state of development. The study of translation norms should be developed then from a more cultural perspective. In doing so, translation norms could lead to some sort of universals of translation, as Toury's theory longed for some time ago. They could even form the description of the history of translation in any culture (Hermans, 1999: 91)

This research is developed from this ideological and cultural perspective of translation norms.

\section{Translation norms in literary transla- tion: a case study}

\subsection{Keys to the study of the reception of poetry through translations}

In general terms, this research relies upon the consideration that translation is an act of communication linked to a double socio-cultural context, that of the original text and that of the translated text ${ }^{4}$. Accordingly, translation is regarded as a very complex form of reception influenced by the factors and participants acting in two different communicative situations.

Moreover, a double reception takes place in any kind of translation within the communicative space of the translated text: the reception made by the translator of the original text, on

4 According to a previous research of the author of this article, "it is preferred to name the translation as translated text because in this way we emphasize the possibility of existence of diverse translations of the very same original text. The translation process is an infinite one, that is, it does not end with a single translation; this is the reason why it is not advisable to use other names such as target text, which implies a concept of translation as a definite process" (Enríquez Aranda, 2007b: 9). This opinion is shared by other scholars. See, for example, Vidal Claramonte (1995: 70): "The different translations of the same text are equally valid as they have been done according to the norms of the corresponding historical period". In this research, both translated text and translation are used to refer to the final product of the act of translation. 
the one hand, and the reception made by the receptors of the translated text produced by the translator, on the other hand. The translator's reception can or cannot be influenced by the reception of the first receptors of the original text-and by the reception of its subsequent receptors along time, if it is the case. The reception of the original text made by the translator determines the way in which the translator faces the translation itself; in this sense, translator's reception specifically influences the reception that the final receptors belonging to the translation system are going to have of the translated text. This double reception present in the translation process obviously exerts a big power into the translation system. Thus it can be assumed that translations are a valid instrument to analyze the complex dual reception of the original texts in a given translation system.

Coming to the grounds of research in literary translation, the methodology to study translation as a form of dual reception of literary texts should be interdisciplinary.

From a theoretical point of view, the fundamentals of this research should be based on the premises given by Reception Theory, Comparative Literature, Descriptive Translation Studies and the new cultural areas of social, historical and ideological interests which are in vogue in present Translation Studies. Reception is studied then from two different disciplines: Literary Theory and Translation Studies (Enríquez Aranda, 2007b) $)^{5}$.

From a practical point of view, the study of translation as a form of reception needs an approach based on both contextual and textual analysis of the translated texts. Any research corpus must be analysed in this sense (Enríquez Aranda, 2010).
In the first place, as part of the contextual analysis, the following aspects need to bestudied:

1. The communicative situations of both the original texts and the translated texts.

2. The physical description of the translated texts-i.e. structure, external and internal presentation, and diffusion-and of their main paratexts-i.e. prologues and notes.

3. The people who are responsible for the production and reception of the translated texts, that is, publishing houses, translators and other people and/or institutions involved in the translation process, above all, translation initiators and pro-translators.

In the second place, becoming part of the textual analysis, two other aspects related to the translation method need to be considered:

1. The selection of the translation corpus: the nature of the selection and the translation canon derived from this selection as well as the evolution along time of the selection itself are the main aspects that can be dealt with. Statistical methods should be positively applied at this stage.

2. The translation techniques used in the linguistic level: if this methodology is used in the translation of poetry, the study of the metrical level reveals itself to the researcher as a logical option. In this sense, the study of the poem, the stanza form, the rhyme distribution and the syllable schema of both the original texts and the translated texts becomes an original and fundamental approach to the translation techniques used in the metrical level ${ }^{6}$.

This methodology covers both the study of the extra-linguistic level or contextual analysis and the study of the linguistic level or textual

5 See Enríquez Aranda (2007b), where a complete review of the theoretical connection between reception and translation is offered, giving detailed and critical bibliography on the matter from different perspectives.

6 In this study the terminological difference drawn by Hurtado Albir (2001: 249) is used: the method is understood as the translator's approach to the whole of the original text according to certain defined principles; the technique is thought to be the concrete application of those principles in the resulting text; the translation strategy is related to the specific mechanisms used to solve problems during the translation process. 
analysis. It runs from the cultural macro-level of translations to their linguistic micro-level, following the order settled by Lefevere (1992a: 13): culture, text, text structure, paragraphs, lines, sentences, and words.

Other previous methodological contributions have been considered, too. Milestones in the methodology of practical descriptive translation cases are the early approach to the phenomenon made by Lambert and Van Gorp (1985) within the Manipulation School, the tripartite methodological proposal made by Toury (1995), the regular items of descriptive study defended by Venuti (1992, 1995, 1998), and the global methodology outlined by Peña (1997), who considers the description of translations a compulsory methodological step to make in any study of translation.

\subsection{An overview of John Keats's transla- tions into Spanish}

\subsubsection{Research corpus in context}

During his lifetime and since, the English Romantic poet John Keats (London, 1795 - Rome, 1821) ${ }^{7}$ inspired numerous other authors, poets, and artists, and he universally remains one of the most widely read and studied 19th century poets. However, "until recent times, Keats was a stranger in Spain, and very less appreciated. Only in the last three decades [referring to the 30s, 40 s and 50s], maybe due to some nice trans- lations, Keats has started to be read and loved" (Cano, 1956: 256).

Since then his works have been - and are still being - translated and retranslated ${ }^{8}$ in Spain from the beginning of the 2oth century.

The research corpus used in this study is composed of the Spanish 11 isolated translations ${ }^{9}$ of Keats's poetry published in Spain during the 2oth century containing Keats's odes and/or sonnets. Isolated translations are considered to be the most consolidated form of literary diffusion of Keats's poetry in the Spanish literary system, as opposed to other means of diffusion of foreign literature like journals, anthologies or other kinds of publications (critical studies, doctoral dissertations, didactic books, recordings...). The original textual corpus is restricted to the 11 odes and 62 sonnets that Keats wrote during his lifetime. This selection shows two proven facts: firstly, that this is the most representative group of poems in Keats's poetic production in quantity and in quality, and, secondly, that it is a corpus both wide and limited enough to allow significant conclusions on the reception and normative spheres ${ }^{10}$.

\subsubsection{Physical description of transla- tions}

The descriptive method proposed by Lambert and van Gorp (1985: 48 and 52) comprises a first step focused on the study of preliminary

7 Five Keats's biographies of international renown are, in chronological order: BATE, Walter Jackson, 1963: John Keats, London: Chatto \& Windus; GitTings, Robert, 1968: John Keats, Harmondsworth: Penguin Books; Barnard, John 1987: John Keats, Cambridge \& New York: Cambridge University Press; Coote, Stephen, 1995: John Keats. A life, London: Hodder \& Stoughton, and Roe, Nicholas, 2012: John Keats. A New Life, New Haven \& London: Yale University Press. They offer an exhaustive study of Keats's life in connection with his works.

8 In general terms, retranslation means the translation made after the first translation of any work (Berman, 1990: 1). To gain an insight into this concept and its relation to the development of a literary system, see Enríquez Aranda (2007a).

9 By isolated translations it is meant the translations published in a volume entirely devoted to the complete or partial diffusion of the literary work/s of one particular author. To access the list of the primary sources used in this research with their corresponding identifying codes, see Section 5.1.

10 Three more Spanish isolated editions of Keats's poetry containing Keats's odes and/or sonnets have been published in Spain in the 21st century. In chronological order: RIVERO TARAVILLO, Antonio (translation), 2005: John Keats. Poemas, Granada: Comares (bilingual edition); LOBARTE FONTECHA, Rafael (translation), 2009: John Keats. Antología poética. Odas, sonetos, otros poemas, La víspera de Santa Inés, Zaragoza: Olifante Ediciones de Poesía (bilingual edition) (also published as an e-book in 2012); SILES ARTÉS, José (translation), 2012: John Keats. Odas, Madrid: Ediciones Librería La Celestina (bilingual edition). Although these translations are not included in this research due to self-imposed temporal research restrictions, it is worth mentioning them here as symbols of the interest that Keats's poetry still arouses in Spain in the new millennium. 
data, that is, the data obtained from the observation of the physical features of translations and from the analysis of their paratexts. This is what Toury (1995: 181-192) calls the contextualization of a translation. He stresses the special importance of the extra-textual sources or paratexts as a means of comprehending the external data of the translated texts. Venuti's methodological proposal (1992, 1995, 1998), deduced from the case studies he deals with in his works, also includes the examination of the physical characteristics of the books, the record of the translator's name, the copyright rights and the analysis of the prologues made by translators. According to him, the sales numbers should be considered part of the diffusion of the translation, too. Peña (1997: 21-24, 27-35 and 44-47) emphasizes the extra-linguistic level, which consists of the presentation of the translated text, the type of translation and the translator's explicit interventions through paratexts.

\subsubsection{Structure and presentation}

Every translation volume has the following items distributed in different ways: front cover, front flap, title page, body matter (index, prologue, bilingual text), colophon, back cover, and back flap. Volumes are small, as usually are poetry books, and their binding and paper are of excellent quality. Only in the case of T3 the paper and the printing are of low quality. $\mathrm{T} 4$ and $\mathrm{T} 5$ are singular as they have a plain appearance, similar to that of a poetry notebook attached with staples.

The most remarkable information present in the front covers and in the title pages of these volumes are the name of the author, Keats, and surprisingly enough, the name of the translator. The initial visibility of translators is then guaranteed except in the case of T3, where the transla- tor's name is lost in a bunch of data distributed in the title page.

However, there is not full coincidence regarding the name given to the act of translation. Whereas half the translations (T2, T3, T5, T6, T7 and $\mathrm{T} 8$ ) are defined by means of the specification of the kind of edition (bilingual) or by means of the specification of the translation method (translation, version, literal translation), the other half (T1, T4, T9, T10 and T11) do not state explicitly the kind of edition or the translation method used. All of the volumes are bilingual except for T6. Most of them, except for T1, T4 and T5, include advertising notes of the publishing houses.

The care used in the external appearance of these volumes is similar to the care used in their internal appearance. No misprints or a scarce number of them (less than 5) are shown in most volumes, except for T3 and T6. The disposition of the text observes the Spanish language tradition, without capital letters at the beginning of the verses (contrary to English language tradition). T2 and T10, however, use capital letters in the first word of the initial verse of every poem.

\subsubsection{Paratexts and diffusion}

The most important paratexts ${ }^{11}$ are prologues and notes, although there are other minor paratexts, such as illustrations, acknowledgements, dedications, quotations or even an advertising note in T2 or a bookmark in T10. Prologues have information on the translation process in half the translations (T2, T7, T9, T10 and $T 11)$, while the rest of prologues (corresponding to T1, T3, T4, T6 and T8) do not mention the translation process at all. T5 does not have a prologue. Notes, when existing, are philological, so they do not offer any information on translation. They offer information, however, on linguistic or contextual data.

11 In this research paratext means every textual or non-textual material that surrounds the main text. More information about the interpretation of this concept within Translation Studies can be found, scattered, in the following books: Arias (2000: 181), Gallego Roca (1994: 165), Lambert and Van Gorp (1985: 48), Lefevere (1992a: 13-14), Peña (1997: 44-47), Pym (1998: 64), and Toury (1980: 57; 1995: 65). Genette (1982, 1987), Kovala (1996), Simon (1990) and, more recently, TahirGürçağlar (2002) and Gil-Bardají et al. (2012) have studied this issue specifically. 
Regarding their diffusion, the oldest translations are out of the present commercial circuits, so that the only way to access them is by consulting them in libraries. Some translations $\left(T_{1}\right.$, T2, T4, T5 and T11), due to their limited edition or their high price, are restricted to an exclusive group of intended readers ${ }^{12}$. Other translations (T3, T6, T7, T8 and T9) are, however, accessible to a wider group or readers. Halfway between them T10 is found, with a wide edition and a high price but easily reachable in any bookshop.

\subsubsection{People in charge of translations}

Within Lambert and Van Gorp's (1985: 4853) practical procedure to study literary translations, the analysis of the people in charge of translations is included in the fourth step, focused on the study of the systemic context in which translations are produced and received. For Toury (1995: 181-192), the people in charge of translations should be taken into account in the first part of the description, known as the contextualization of a translation. Publishing houses and translators should be of main interest as part of the study of the genesis of the translation and of the genesis of the translation process. Venuti (1992, 1995, 1998) suggests making interviews to publishers, agents and translators. Interviews with publishers and agents serve to clarify the underlying purposes underneath the publishing processes of translations, while interviews with translators hope to examine translation methods from first-hand testimonies. In this sense, translation contracts are valuable. Peña (1997: 25-27 and 35-37) considers the study of the client, the pro-translator and the translator a very important part of the description of translations because, together with the author of the original text and the receptors of both the original text and the translated text, are active participants in the translation process.

\subsubsection{Publishing houses}

There are four kinds of publishing houses according to the material they publish and the intended reader they address this material to:

1. Poetry publishing houses: Yunque (closed) (T1), Rialp (T2), Visor (T6), Hiperión (T7), Ediciones Canarias (closed) (T9) and Pre-Textos (T10) usually publish culturally important books, paying special attention to Spanish thinking and literary creation either in verse or in prose. The intended reader is an informed reader who wants to widen his/ her culture or simply enjoy literature. Visor and Hiperión are important Spanish poetry publishing houses nowadays. Ediciones Canarias could be also considered an author publishing house as its influence circle was restricted mainly to the Canary Islands.

2. Author publishing houses: José Siles Artés (T4), Judit (closed) (T5) and Pavesas. Hojas de poesía (T11) are very small publishing houses which were founded by authors who published in them (Siles Artés, and Velo and Amusco) or by people who took great care of the publishing process (José Luis Puerto). The selected material, then, responds to the personal feelings of the editors, who publish it having in mind an informed reader who tastes literature.

3. Commercial publishing house: Ediciones 29 (T3) publishes fiction books on different matters. The intended reader is a general public, normally non-informed people.

4. Academic publishing house: Cátedra (T8) focuses its activity on publishing full noted classics, although it also publishes about general studies in humanities. The intended reader is an informed reader who searches for philological rigor. 
Curiously enough, there is not a university publishing house.

The collections in which these translations are published confirm the above stated typology. The commercial publishing house and the poetry publishing houses have their own collection of poetry. The academic publishing house includes $\mathrm{T} 8$ in a collection of foreign literature, without distinguishing among literary genres. The author publishing houses, due to their intrinsinc constraints, do not have their own collections.

All these publishing houses are based on the traditional publishing industry zones, that is, Madrid (T2, T6, T7, T8 and T10) and Barcelona (T1, T3 and T5), although the number of translations published in other places such as Murcia, Tenerife or Segovia (T4, T9 and T11) equals the number of translations published in Barcelona.

\subsubsection{Translators}

Translators are mainly men who work on their own (T3, T4, T6, T7, T8, T10 and T11). There are only two female translators ( $\mathrm{T} 1$ and $\mathrm{T} 2$ ). In $\mathrm{T} 5$ and $\mathrm{T} 9$ both male and female translators share responsibilities, although it is an unbalanced responsibility in the case of the latter, as the Taller is formed of seven male translators, four male collaborators and only one female translator.

If attention is to be paid to the individual or collective authorship of the translations, only T5, T8 and T9 are collective translations, being two, three and twelve the exact number of translators in each of them.

Other data about translators have not been so readily accessible: the translators' profession, their competence in foreign languages or their motivation to do the translation of Keats's poetry. In T3 and T5, it was impossible to find out any information (Sánchez and Velo), so they are not included in the following analysis. However, some translators filled in a questionnaire where they explained their professional background and their personal motivation to undertake the translation of Keats's poetry.

According to their professional activity, translators are:

1. Professionals-translators: professionals belonging to working areas different from translation who occasionally translate:

1.1. Teacher who translates: Nicolás Payá(T8).

1.2. Writers who translate: Mulder (T1) and Miró (T2).

1.3. Teachers-writers who translate: Siles Artés (T4), Amusco (T5), Taller (T9) and Oliván (T10 and 11).

2. Translators-professionals: professionals belonging to working areas different from translation who also translate professionaIly:

2.1. Teachers-translators: Martínez Luciano and Teruel Pozas (T8).

2.2. Writer-translator: Martín Triana (T6).

2.3. Teacher-writer-translator: Valero (T7).

None of them is a full-time translator, as they have to combine this activity with secondary or university teaching and/or writing or reviewing.

Foreign language training of most translators is academic, except for the eldest female translators (Mulder and Miró), whose foreign language training relied upon an informal training based on frequent travels abroad. The reasons for this could be both the time when they lived and their exclusive dedication to writing.

Translators' motivations to translate Keats have been rescued from the questionnaires, but most of them confirm suppositions arisen from some prologues: academic interest (Teruel Pozas), personal interest (Siles Artés, Valero, Martínez Luciano and Oliván) or both interests together (Taller). Miró was also moved by personal interest, as it can be deduced from her prologue. 


\subsubsection{Other people and/or institutions}

There are other people and/or institutions that participate in the edition, production and distribution of translations. These participants in the translation process are always linked to the publishing world, or to the literary or arts world. The most important figures, as far as translation is concerned, are the initiator and the pro-translator.

In every translation, the translation initiator, that is, the one who selects the material to be published (Hermans, 1996: 26-29), takes the form of two different agents: on the one hand, people belonging to the publishing or literary worlds with a high intellectual capacity and high financial power, and, on the other hand, the publishing houses themselves. In T4 and T5, the translation initiator is the very same translator as s/he is his/her own editor.

The pro-translator role, that is, promoting the translation (Peña, 1997: 26), is carried out by the previous translations of Keats's poetry published in Spain, such as translations included in anthologies and the isolated translation that Manent did into Catalan in $1919^{13}$. These translations were the first translations known in Spain in the 2oth century. Other translations followed: journals, critical essays, or original poetic works. Even the translations studied as this research corpus act themselves as pro-translators among them as long as their various publications motivate other future re/translations. Translations published in Latin America in isolated translations, anthologies, literary or poetic journals or even original poetic works with Keats's reminiscences act as pro-translators of the translations published in Spain. Last but not least, translations of Keats's letters published in Spain or Latin America or other translations into peninsular languages (Catalan or Galician) can be consid- ered pro-translators as well. It is finally worth mentioning in this point the influence exerted by literary prizes and institutional grants for translations, which differ in T2, T3, T6, T7, T8 and T10.

\subsubsection{Translation method}

The first theoretical and practical contextual description of translations that also integrates the textual analysis of the translated texts can be found in Lambert and Van Gorp (1985: 48-53). From their perspective, the main factors intervening in the translation process are the author, the text and the receptor. The study of the interactions among them has to deal with the analysis of the macro-level (second step) and the micro-level (third step). The order runs from the study of the global structure of the translated text to the study of the minor phonetic, syntactic and lexical structures. Hypotheses about the translation method could be drawn and analyzed from the observation of the translation techniques the translators used. Toury (1995: 181-192) gives the second place in his tripartite descriptive methodology to the comparison of the original text with the translated text. To know the translation norms that define translation processes, it is necessary to observe directly the original and the translated texts. Venuti $(1992,1995,1998)$ also defends the linguistic comparison between the original and the translated text in order to locate translation techniques and strategies that define the translation process. For Peña (1997, 20-24, 27-35 and 37-54), a correct description of translations has to include the analysis of the objects participating in the translation (the original and the translated texts), the type of translation, the frame that surrounds the translation, the constraints, the translator's in/visibility, the fidelity towards the original text, the temporal factor and some specific linguistic features.

13 Manent, Marià (translation), 1919: John Keats. Sonets i odes (prologue by Eugeni D’ORS), Barcelona: Publicacions de La Revista (Lírics Mundials, 4). This translation, as well as the rest of translations or works mentioned as pro-translators in this study, will be accurately listed in a forthcoming Keats's bibliographical study by the author of this article. 


\subsubsection{Selection of the translation cor- pus}

As stated before, the translation corpus comprises the original texts of the 11 odes and the 62 sonnets that Keats wrote during his lifetime. These poems have awoken great translation interest in the 2oth century Spain: out of the 13 isolated editions published, up to 11 editions include translations of these poems ${ }^{14}$.

There are two main reasons behind this interest: firstly, these poems were very well received by the critics and the general public in the United Kingdom, a success that was introduced early into the Spanish translation system through English literature anthologies ${ }^{15}$; secondly, there has been a translator tradition in the Spanish literary system that dates back from 1919 thanks to the aforementioned Catalan translation done by Manent.

The primary corpus of the original texts is not fully translated in all translations; on the contrary, selection processes have been applied to it. $T 7$ is the most complete translation, while $\mathrm{T} 4$ and $\mathrm{T} 9$ are the most incomplete ones. Translators are the ultimate responsible people for this selection, so it can be affirmed that the selection of the translation corpus can be considered a distinctive feature of the translation method, as valid as translation techniques are, for example. The selection of the translation corpus is visible in all translations, whereas the original edition used in them is only specified in six cases, even though all translations (except for T6) are bilingual. Maybe translators do not want to minimize the prominence of Keats specifying the edition works of his poems, in which the editor's figure is of outstanding relevance; maybe translators do not consider it important information as long as original texts are always present.

The selection of the translation corpus carried out in the 11 translations offers a complete sample of Keats's odes and sonnets that can be studied using statistical methods. Both quantitative and qualitative data can be interrelated with each other.

Calculating translation average, for example, provides three main conclusions.

In the first place, the odes and the sonnets form a research corpus that is appropriate enough to carry out a satisfactory textual comparison because they are translated an average of more than three times each (4.36 times in the case of the odes and 3.60 times in the case of the sonnets).

In the second place, translation average allows the classification of the odes and the sonnets according to those poems that are translated fewer times (0-3 times in the case of the odes and $0-2$ in the case of the sonnets), those that are translated an average number of times (4-5 times in the case of the odes and 3-4 in the case of the sonnets), and those that are translated many times (6-11 times in the case of the odes and 5-11 in the case of the sonnets).

In the third place, from this classification it can be deduced that a high percentage of the global sample has been translated an average number of times or more $(63.64 \%$ in the case of the odes and $74.19 \%$ in the case of the sonnets), which proves the hypothesis of the great interest in translating Keats's odes and sonnets held before.

Nevertheless, the statistical study is limited. It does not offer the chance to interpret the

14 To the list of the primary sources used in this study included in Section 5.1., two more isolated translations of Keats's poetry into Spanish can be added (in chronological order): UGALDE RAmo, P. L. (prologue, chronology, unpublished translation and notes), 1977: John Keats. Endymion/John Keats. Endimión, Barcelona: Bosch (Erasmo) (bilingual edition), and Pérez Romero, Carmen and Pablo Zambrano Carballo (translation, prologue and notes), 1996: John Keats. The Eve of St. Agnes/ La víspera de santa Inés, Huelva: Universidad de Huelva (Arias Montano, 11) (bilingual edition).

15 To have more information about the Spanish translation anthologies of the English Romanticism, see Enríquez Aranda (2004). 
importance of the odes in comparison with the sonnets as in some cases the balance is tipped in favour of the odes (average of translation) and in other cases the balance is tipped in favour of the sonnets (frequency of translation). The attention paid to each group of poems by the selectors of the translation corpus is not measurable. However, it can be said that the translations that include odes and sonnets pay more attention to the odes.

The selection of the translation corpus is determined by the canon authorities that exert their patronage (Lefevere, 1992b) or control over the translation system: the people responsible for the translations-mainly but not exclusively the translators - and the receptors to whom the translations are addressed.

Ideological and aesthetical factors influence on these authorities and, consequently, on the selection. On the one hand, aesthetical factors lead to a possible translation canon of Keats's poems into Spanish, formed of the odes and the sonnets that have been translated over the average. These poems were the most successful in the English Romantic period. Thus their Spanish translation is considered very important as a means of transmitting Keats's aesthetical value. On the other hand, ideological factors related to the special historical and social circumstances of the 2oth century Spain explain the evolution in periods that the selection has suffered through retranslations ${ }^{16}$.

\subsubsection{Translation techniques}

A metrical study using as a corpus the textual pairs made up of the original and the translated texts of Keats's odes and sonnets is worthy to be carried out as the conclusions can be related to the translation techniques used by translators. The levels of the poem, the stanza form, the rhyme distribution and the syllabic scheme may be the items to research about.

All translations share two common features: they treat the translation of the odes and the sonnets equally, and they respect the poem and the stanza form of the original texts, although they are obliged to make some changes derived from their common decision to avoid rhyme. However, translations differ in the ways they distribute the rhyme and the syllabic scheme. These differences make it possible to establish a typology of translations:

1. $T 1, T 2, T 3, T 4, T 5, T 6$ and $T 8$ are free verse translations.

2. T7, T9, T10 and T11 are metrical translations, being:

2.1. Metrical translations in alexandrine verse (T7 and T9).

2.2. Metrical translations in silvas (T10 and TII) $)^{17}$.

Both metrical translations are analogical forms of translations, according to Holmes's (1994 [1988]: 23-33) terminology. The analogical form refers to translations that use a culturally equivalent metrical form to that of the original text but in the poetic tradition of the translation language.

Actually, all translations are on the whole translations-approximations, in terms of Etkind (1982: 19-22), as they follow partial aesthetic programmes based upon the poem and the stanza form of the original texts, but they differ from the original poems in the rhyme distribution and in the syllabic scheme.

These approximations to the original texts involve losses and gains. As the main loss it can be considered the proven fact that translations do not reflect the technical evolution that Keats

16 To have more information about this point, see Section 3.3

17 The silva is a Spanish poem that has not stanzas but verses of a regular number of syllables: seven and eleven. See Domiguez Caparrós, José, 1993: Métrica española, Madrid: Síntesis, or Quilis, Antonio, 1999: Métrica española, 11th edition, Barcelona: Ariel, for more information on Spanish metrics. 
experienced in the composition of the odes and sonnets, mainly based on rhyme plays. As the main gain it can be stressed the metrical serious ness used by most translators in their tasks.

In this research, the translation method is understood as the way in which the translator undertakes the translation process from the very first selection of the translation corpus to the choice of the translation techniques that are more appropriate in the metrical level.

In this sense, it can be said that translations use mixed methodological approaches governed by extra-linguistic and linguistic factors.

Regarding extra-linguistic factors, all translations follow a philological method. Four features support this:

1. All translations, except for T6, are bilingual editions; the translation process becomes visible by highlighting its philological nature.

2. Prologues and notes have a marked philological content in most translations.

3. The selection of the translation corpus mainly follows the importance that the original texts have in the original system. This importance is based on philological critical reviews of Keats's original works.

4. Receptors of translations are generally informed readers, except in the case of T3.

Regarding linguistic factors, exclusively related to the translation techniques used in the metrical level, all translations follow a literal method as long as they respect the poem and the stanza form of the original texts. However, metrical translations (T7, T9, T10 and $T 11)$ share an interpretative-communicative method, too. The metrical decisions related to rhyme distribution and syllabic scheme are based on the comprehension and reformulation of the sense of the original text so that the translated text keeps the same purpose of the original text causing the same effect on the receptor. Free verse translations (T1, T2, T3, T4, T5, T6 and T8) follow a free method in their rhyme distribution and syllabic scheme ${ }^{18}$.

\subsection{John Keats and his image in Spanish: a normative issue}

From these data, it can be affirmed that Spanish translations of Keats's odes and sonnets included in isolated editions published in Spain in the last century are a valid instrument to analyze the reception of Keats's original poetry in the 2oth century Spanish literary system.

From this study, translators' different receptions of the original texts can be known. These receptions, influenced by the socio-cultural context in which translation takes place, determine the choice of the translation method and bias the final reception of the translation. The study of different translators' approaches to Keats's most representative poems (odes and sonnets) shows different readings of his works. Consequently, it may be assumed that Keats's image evolves along with his retranslations in the 20th century Spanish literary system. This evolution is first and foremost conditioned by two main forces: the literary and historical evolution, on the one hand, and the thinking about translation of poetry, on the other.

\subsubsection{Literary and historical norms}

Translations can be divided into three different periods, according to the literary and historical evolution of Spanish tradition in the 2oth century.

\subsubsection{First literary and historical pe- riod}

The first period comprises the four decades of Franco's regime. At that time, the first books 
devoted exclusively to Keats's translations were published. These translations were $\mathrm{T}_{1}$ and $\mathrm{T}_{2}$, published in 1940 and in 1950 respectively.

There are two main reasons that explain this late arrival of Keats's poetry into the Spanish literary system in the 2oth century as well as the short of isolated editions during the first 75 years of that century.

The first reason is a social one; it refers to the severe financial and social hardship that the publishing industry underwent after the Civil War (from 1939 onwards). Short economical means, intellectuals' deaths or exiles, or ideological censorship contributed to this hardship.

The second reason is a literary one; it refers to the supremacy of French Parnasian, Symbolist, and Impressionist Movements as the key foreign influences on Spanish literature during its Silver Age ( \pm 1868-1936).

During this time, translations, produced in limited and expensive editions, were accessible only to a selected group of readers. The female translators were writers who occasionally devoted themselves to literary translation. They did not have a formal education in foreign languages, which was limited to travels abroad and some informal lessons (English was not an academic degree in Spain until 1952). The most important publishing houses were based in Barcelona and Madrid. The odes and sonnets specially selected for these translations transmitted a very romantic (in the sense of emotive) image of Keats.

\subsubsection{Second literary and historical period}

The second period runs during the years of transition to democracy, between 1975 and 1976, when T3, T4 and T5 were published.

In only two years' time more translations of Keats were published than in the rest of the century. Thanks to a rapid financial and social development of Spain and thanks to Spain's opening-up to new political and intellectual ideas from the 6os onwards, the interest for isolated translations of Keats's poetry awoke from 1975. Nevertheless, translations kept still being accessible only to a group of selected readers.

These three translations differ in two aspects. Firstly, the nature of their publishing houses is different: T3 was published in a commercial publishing house by a translator-professional, whereas T4 and T5 were published by author publishers. Secondly, the selection of the translation corpus varies: T3 is the first attempt to offer a global image of Keats by reproducing nearly his complete odes and sonnets, while T4 and $T 5$ reflect the beginning of the aesthetic freedom that was a main characteristic of later translations. However, these translations come into a unique group both because they were published in the same years and because they represent the transition towards the new coming period. In other words, in these translations it can be appreciated a tendency towards translations made by male translators, and, at the same time, as well as the possibility of collective translation is offered in them for the first time. Publishing houses were placed mainly in Barcelona.

\subsubsection{Third literary and historical pe- riod}

The third period goes from the first years of democracy until the end of the century. T6, T7, T8, T9, T10 and T11 were published between 1982 and 2000.

The number of Keats's translations included in isolated editions substantially increased in this last period, although being a short one. Interest towards Keats's poetry was finally consolidated from 1995, in the bicentenary of Keats's birth. These translations widened their potential receptors, although still being specialized ones.

Diversification is the best word to define translations in this period. Literary and historical constraints began to be overcome by the personal power of translators, following Timoczko's (2007) empowering vision. 
Translations were published in publishing houses devoted to poetry, in academic publishing houses or by author publishers. The publishing epicentre changes to Madrid and other places. Writers and teachers who also translate professionally translate T6, T7 and T8, whereas writers and teachers who translate occasionally translate $T 9, T 10$ and T11. Foreign language training of most translators comes mainly from formal education. Translation becomes definitively a male activity, and individual translations coexist with collective translations, although tipping the balance in favour of the former. All these translations have selected odes and sonnets with different commercial and symbolic value, depending on the interests of the translators or on the interests of the publishing houses, and according to the potential readers and the aim they pursue.

The three literary and historical periods in the evolution of the translations of Keats's poetry into Spanish must be understood as an interesting methodological tool of classification but not as a restrictive one. As well as the socio-cultural context in which translations are produced and received is categorized only to facilitate in terpretation, the three periods of evolution are permeable.

\subsubsection{Translatological norms}

The metrical study underwent by the translations in this study shows a temporal evolution in the translation techniques which gathers translations in two different periods, according to the evolution of the thinking about the translation of poetry in the 2oth century Spain.

\subsubsection{First translatological period}

Free verse translations were produced from 1940 to 1997. Idealism dominated over the thinking of translation during the first third of the 2oth century and it strongly influenced the practice of translation. This activity was considered a task doomed to failure. Under these premises the first translations were carried out ( $\mathrm{T} 1, \mathrm{~T} 2, \mathrm{~T} 3$, T4, T5, T6 and T8) following a free method.

Despite its name, these translations deliberately chose free verse as a means of conveying literal content without metrical constraints. This is the favourite method of the oldest poets, as long as it has always been the most used traditional form in the translation of poetry. Translators do not express any opinion on the translation process

\subsubsection{Second translatological period}

Metrical translations were produced from 1995 to 2000. These translations chose the interpretative-communicative translation method. They are the youngest translations (T7, T9, T10 and T11) which go over Idealism and recreate the original poems by using culturally equivalent metrical forms in the poetic tradition of the translation culture. Translators make themselves visible through prefaces to their translations whenever they want to specify the metrical patterns they choose.

Although different in evolution, all translations share two poetically inherent features.

Firstly, it is hardly difficult for them to get free from the old conception of poetry as an impossible task. They all share the following underlying characteristics:

1. Metrics is the main feature to worry about when translating poetry.

2. Editions are usually bilingual. Translator becomes visible even in the same places where the author's name, Keats, is written.

3. They tend to follow philological and literal methods as the great majority of readers are cultivated people who want to know Keats's poetry in Spanish, either by personal or by academic interests.

Secondly, translators gain in visibility, and their role is only limited, partially or totally, by the publishing houses. Translation of Keats's 
poetry is still a task headed by translators who are poets themselves and feel affinity for Keats's works and figure. Keats's translations are out of commercial circuits.

\section{In conclusion}

Normative translator behaviours have been defined, which allows a classification of translations according to the natural evolution of the socio-cultural context where translations are produced and received.

Translator behaviours described in this research and their evolution along time are understood within the concept of translation norms as long as these norms are conventions that represent the defining values of the Spanish literary system in the 2oth century and, by extension, the defining values of the production and reception of Keats's poetry within it.

Conclusions can be extrapolated to the study of the most common practices followed in the translation of poetry in the past century Spain as long as it has been proved that translation moves within a normative socio-cultural sphere. Theoretical and methodological fundamentals appropriate to the original study of translation as a form of reception of foreign literature have been settled. This research joins the incipient but promising literature that stresses the great interest Translation Studies have in the reception issue nowadays, only studied by the Reception Theory within Literary Studies so far.

But this proposal is still open. It should be completed with other kind of studies comprising, for example, textual analysis in different levels of language, translation reviews, or Keats's imprint on Spanish Parnassus - these two last possibilities being part of a deeper perspective on the reception matter ${ }^{19}$. Similar studies applied to other Romantic poets, such as Wordsworth, Coleridge, lord Byron o Shelley would be very welcomed. As it would be the same kind of study but dealing with Latin American translations, or translations in other languages.

At the same time, subsequent research attached to different fields, i.e. Applied Linguistics, Synchronic Linguistics, and Literary Theory, Analysis and Criticism, would be a very important step towards interdisciplinarity, which could be even more reinforced by implementing the modern IT statistical tools normally used in Sociology_as Toury (1995: 69) stated some time ago-, for example IBM SPSS Statistics for quantitative data analysis or atlas.ti for qualitative data analysis.

\section{Cited bibliography}

\subsection{Primary sources ${ }^{20}$}

\section{TRANSLATION}

\begin{tabular}{c|c|l} 
IDENTIFYING CODE & EDITION YEAR & \multicolumn{1}{c}{ TRANSLATION } \\
\hline T1 & 1940 & $\begin{array}{l}\text { Mulder, Elisabeth (prologue, selection and translation): John Keats, } \\
\text { Barcelona: Yunque (Poesía en la mano, 20; Poetas ingleses, 3) (bilingual } \\
\text { edition). }\end{array}$ \\
\hline T2 & 1950 & $\begin{array}{l}\text { MiRó, Clemencia (selection, version and prologue): John Keats. Poesías, } \\
\text { Madrid: Rialp (Adonais, XXVIII) (bilingual edition). }\end{array}$ \\
\hline T3 & 1975 & $\begin{array}{l}\text { SAncheZ, Arturo (translation): Keats. Poesía completa (prologue by Atilio } \\
\text { PentImaluI), 2 volumes, Barcelona: Ediciones 29 (Poesía Río Nuevo, XIII-XIV) } \\
\text { (6th edition 1997, bilingual edition). }\end{array}$ \\
\hline
\end{tabular}

19 To have more information on this reception issue applied to literary translation from a methodological point of view, see Enríquez Aranda (2010)

20 Primary sources are listed in chronological order, not in alphabetical one. They are given each the identifying code used in the research. 


\begin{tabular}{|c|c|c|}
\hline T4 & 1976 & $\begin{array}{l}\text { Siles ARTÉs, José (translation): La oda a un ruiseñor de John Keats, Murcia: } \\
\text { José Siles Artés (bilingual edition). }\end{array}$ \\
\hline T5 & 1976 & $\begin{array}{l}\text { Velo, María-Jesús y Alejandro Amusco (version and translation): John Keats. } \\
\text { Trece Sonetos, Barcelona: Judit (bilingual edition). }\end{array}$ \\
\hline T6 & 1982 & $\begin{array}{l}\text { Martín TRIANA, José María (selection, literary translation and notes): John } \\
\text { Keats. Sonetos, odas y otros poemas (preliminary essay by Matthew } \\
\text { ARnold), Madrid: Visor (Visor de Poesía, 134) (2nd edition 1995). }\end{array}$ \\
\hline T7 & 1995 & $\begin{array}{l}\text { VaLERo, Alejandro (translation, prologue and notes): John Keats. Odas } \\
\text { y sonetos, Madrid: Hiperión (Poesía Hiperión, 263) (1st reprint 1997, } \\
\text { bilingual edition). }\end{array}$ \\
\hline T8 & 1997 & $\begin{array}{l}\text { Martínez Luciano, Juan V., Pedro Nicolas Paya and Miguel Teruel Pozas (bilingual } \\
\text { edition and translation): John Keats. Poemas escogidos (prologue and } \\
\text { notes by Juan V. Martínez Luciano), Madrid: Cátedra (Letras Universales, 258). }\end{array}$ \\
\hline T9 & 1997 & $\begin{array}{l}\text { Taller de TRAducción Literaria de la Universidad de La Laguna (collective } \\
\text { translation): John Keats. Oda a una urna griega, Tenerife: Ediciones } \\
\text { Canarias (Taller de Traducción Literaria, 4). }\end{array}$ \\
\hline T10 & 1998 & $\begin{array}{l}\text { Oliván, Lorenzo (edition and translation): John Keats. Belleza y verdad, } \\
\text { Madrid-Buenos Aires-Valencia: Pre-Textos (La Cruz del Sur, 331) (bilingual } \\
\text { edition). }\end{array}$ \\
\hline T11 & 2000 & $\begin{array}{l}\text { Olivan, Lorenzo (edition and translation): John Keats. Epístolas y otros } \\
\text { poemas, Segovia: Pavesas. Hojas de poesía (Pavesas. Hojas de poesía, XIV) } \\
\text { (bilingual edition). }\end{array}$ \\
\hline
\end{tabular}

\subsection{Secondary sources}

ArIas, Juan Pablo, 2000: "Imágenes del texto sagrado" in Gonzalo Fernández Parrilla and Manuel C. Feria Garcia (eds.): Orientalismo, exotismo y traducción, Cuenca: Universidad de Castilla-La Mancha, 181-190.

Berman, Antoine, 1990: "La retraduction comme espace de la traduction”, Palimpsestes 4, 1-7.

Cano, José Luis, 1956: "Keats en España (Noticia bibliográfica)”, Papeles de Son Armadans 3(9), 265273.

Chesterman, Andrew, 1997: Memes of Translation. The Spread of Ideas in Translation Theory, Amsterdam \& Philadelphia: John Benjamins.

Enriquez Aranda, María Mercedes, 2004: "Análisis externo de las antologías de traducción españolas del romanticismo poético inglés (1915-2002)", Trans. Revista de traductología 8, 61-74.

Enriquez Aranda, María Mercedes, 2007a: "La crea- ción del canon a través de la retraducción en antologías: imagen romántica en el siglo XX" in Juan Jesús Zaro Vera and Francisco Ruiz Noguera (eds.): Retraducir: una nueva mirada. La retraducción de textos literarios y audiovisuales, Malaga: Miguel Gómez Ediciones, 117-134.

Enríuez Aranda, María Mercedes, 2007b: Recepción y Traducción. Síntesis y crítica de una relación interdisciplinaria, Malaga: Universidad de Málaga.

Enríuez Aranda, María Mercedes, 2010: "La investigación en traducción literaria: aproximación a una nueva metodología" in Elisa Calvo EncInAs, María Mercedes Enriquez Aranda, Nieves Jiménez Carra, Inmaculada Mendoza García, Marián Morón Martín and Nuria Ponce Marquez (eds.): Actas del I Congreso Internacional de Innovación Investigadora en Traducción e Interpretación (ICITIR) (Universidad Pablo de Olavide, Sevilla, 26 y 27 noviembre 2009), Seville: Universidad Pablo de Olavide, 31-49.

ETKInD, Efim, 1982: Un art en crise. Essai de poétique de la traduction poétique, Lausanne: I'Age d'Homme. 
Gallego Roca, Miguel, 1994: Traducción y Literatura: Los estudios literarios ante las obras traducidas, Madrid: Júcar.

Genette, Gérard, 1982: Palimpsestes: Ia littérature au seconde degré, Paris: Éditions du Seuil; trans. C. Fernández Prieto as Palimpsestos. La literatura en segundo grado, 1989, Madrid: Taurus.

Genette, Gérard, 1987: Seuils, Paris: Éditions du Seuil; trans. J. E. Lewin as Paratexts. Thresholds of interpretation, 1997, Cambridge: Cambridge University Press.

Gil-Bardaji, Anna, Pilar Orero and Sara Rovira-Esteva (eds.), 2012: Translation Peripheries. Paratextual Elements in Translation, Frankurt am Main: Peter Lang.

Hermans, Theo, 1991: "Translational Norms and Correct Translations" in Kitty M. VAN LeUven-ZwarT and Ton NaAlJkens (eds.): Translation Studies: The State of the Art (Proceedings of the First James S. Holmes Symposium on Translation Studies), Amsterdam \& Atlanta: Rodopi, 155-169.

Hermans, Theo, 1996: "Norms and the Determination of Translation: A Theoretical Framework" in Román Álvarez and M. ${ }^{a}$ Carmen-África VIDAL (eds.): Translation, Power, Subversion, Clevedon: Multilingual Matters, 25-51.

Hermans, Theo, 1999: Translation in Systems. Descriptive and Systemic Approaches Explained, Manchester: St. Jerome.

Holmes, James S., 1994 [1988]: Translated! Papers on Literary Translation and Translation Studies, 2nd edition, Amsterdam \& Atlanta: Rodopi.

Hung, Eva, 2005: Translation and cultural change: studies in history, norms, and image projection, Amsterdam \& Philadelphia: John Benjamins.

Hurtado AlBiR, Amparo, 2001: Traducción y Traductología. Introducción a la Traductología, Madrid: Cátedra.

Kovala, Urpo, 1996: "Translations, Paratextual Mediation, and Ideological Closure", Target. International Journal of Translation Studies 8(1), 119-147.
LAmBert, José and Hendrik Van Gorp, 1985: "On Describing Translations" in Theo Hermans (ed.): The Manipulation of Literature. Studies in Literary Translation, London-Sydney: Croom Helm, 42-53.

Lefevere, André, 1992a: Translating Literature. Practice and Theory in a Comparative Literature Context, New York: The Modern Language Association of America.

LefeVere, André, 1992b: Translation, rewriting and the manipulation of literary fame, London \& New York: Routledge.

Munday, Jeremy, 2001: Introducing Translation Studies. Theories and applications, London \& New York: Routledge.

Nord, Christiane, 1997: Translating as a Purposeful Activity. Functionalist Approaches Explained, Manchester: St. Jerome.

Paz, Octavio, 1990 [1971]: Traducción: literatura y literalidad, 3rd edition, Barcelona: Tusquets.

Peña, Salvador, 1997: "El traductor en su jaula: hacia una pauta de análisis de traducciones" in Esther Morillas and Juan Pablo Arias (eds.): El papel del traductor, Salamanca: Colegio de España, 19-57.

Pozuelo Yvancos, José María, 1989: La teoría del lenguaje literario, Madrid: Cátedra.

Pym, Anthony, 1998: Method in Translation History, Manchester: St. Jerome.

RABAdÁn, Rosa, 1991: Equivalencia y traducción. Problemática de la equivalencia translémica inglés-español, León: Universidad de León.

SChäfFneR, Christina (ed.), 1999: Translation and norms, Clevedon: Multilingual Matters.

Simon, Sherry, 1990: "Translating the Will to Knowledge: Prefaces and Canadian Literary Politics" in Susan Bassnett and André Lefevere (eds.): Translation, History and Culture, London: Cassell, 110-117. 
TAHIR-GürÇAĞLAR, Şehnaz, 2002: “What Texts Don’t Tell. The Uses of Paratexts in Translation Research" in Theo Hermans (ed.): Crosscultural Transgressions. Research Models in Translation Studies II. Historical and Ideological Issues, Manchester: St. Jerome, 44-60.

Timoczko, Maria, 2007: Enlarging translation, empowering translators, Manchester: St. Jerome.

Toury, Gideon, 1980: In Search of A Theory of Translation, Tel Aviv: The Porter Institute for Poetics and Semiotics.

Toury, Gideon, 1995: Descriptive Translation Studies and beyond, Amsterdam \& Philadelphia: John Benjamins.

VenUtI, Lawrence, 1992: "Introduction" in Lawrence VENUTI (ed.): Rethinking Translation. Discourse, Subjectivity, Ideology, London \& New York: Routledge, 1-17.

Venuti, Lawrence, 1995: The Translator's Invisibility. A History of Translation, London \& New York: Routledge.

Venuti, Lawrence, 1998: The Scandals of Translation. Towards an ethics of difference, London \& New York: Routledge.

Vidal Claramonte, M. ${ }^{a}$ Carmen África, 1995: Traducción, manipulación, desconstrucción, Salamanca: Ediciones Colegio de España.

Vidal Claramonte, M. ${ }^{a}$ Carmen África, 1998: El futuro de la traducción. Últimas teorías, nuevas aplicaciones, Valencia: Institució Alfons el Magnànim.

Wolf, Michaela and Alexandra Fukary, 2007: Constructing a Sociology of Translation, Amsterdam \& Philadelphia: John Benjamins. 